\title{
Organic Agroforestry Long-Term Field Experiment Designing Trough Actors' Knowledge towards Food System Sustainability
}

\author{
Corrado Ciaccia ${ }^{1, *}\left(\mathbb{D}\right.$, Elena Testani ${ }^{1}\left(\mathbb{D}\right.$, Angelo Fiore ${ }^{2}$, Ileana Iocola ${ }^{1} \oplus$, Marta Di Pierro ${ }^{3}$, Giuseppe Mele ${ }^{4}$, \\ Filippo Ferlito ${ }^{5}\left(\mathbb{D}\right.$, Marcello Cutuli ${ }^{5}$, Francesco Montemurro ${ }^{2}\left(\mathbb{D}\right.$, Roberta Farina ${ }^{1}\left(\mathbb{D}\right.$, Danilo Ceccarelli ${ }^{6}$, \\ Alessandro Persiani ${ }^{2}$, Stefano Canali ${ }^{1}$ and Mariangela Diacono ${ }^{2} \mathbb{C}$
}

1 Research Centre for Agriculture and Environment (CREA-AA), Council for Agricultural Research and Economics, 00184 Roma, Italy; elena.testani@crea.gov.it (E.T.); ileana.iocola@crea.gov.it (I.I.); roberta.farina@crea.gov.it (R.F.); stefano.canali@crea.gov.it (S.C.)

2 Research Centre for Agriculture and Environment (CREA-AA), Council for Agricultural Research and Economics, 0125 Bari, Italy; angelo.fiore@crea.gov.it (A.F.); francesco.montemurro@crea.gov.it (F.M.); alessandro.persiani@crea.gov.it (A.P.); mariangela.diacono@crea.gov.it (M.D.)

3 Italian Association of Organic Farmers-Lazio Branch (AIAB-Lazio), 00153 Rome, Italy; marta.dipierro@gmail.com

4 Agenzia Lucana di Sviluppo e di Innovazione in Agricoltura (ALSIA), 75100 Matera, Italy; giuseppe.mele@alsia.it

5 Research Centre for Olive, Fruit and Citrus Crops (CREA-OFA), Council for Agricultural Research and Economics, 95124 Acireale, Italy; filippo.ferlito@crea.gov.it (F.F.); marcello.cutuli@crea.gov.it (M.C.)

check for updates

Citation: Ciaccia, C.; Testani, E.; Fiore, A.; Iocola, I.; Di Pierro, M.; Mele, G.; Ferlito, F.; Cutuli, M.; Montemurro, F.; Farina, R.; et al. Organic Agroforestry Long-Term Field Experiment Designing Trough Actors' Knowledge towards Food System Sustainability. Sustainability 2021, 13, 5532. https://doi.org/ $10.3390 /$ su13105532

Academic Editor: Hayo van der Werf

Received: 30 March 2021

Accepted: 12 May 2021

Published: 15 May 2021

Publisher's Note: MDPI stays neutral with regard to jurisdictional claims in published maps and institutional affiliations.

Copyright: (c) 2021 by the authors. Licensee MDPI, Basel, Switzerland. This article is an open access article distributed under the terms and conditions of the Creative Commons Attribution (CC BY) license (https:/ / creativecommons.org/licenses/by/ $4.0 /)$.
6 Research Centre for Olive, Fruit and Citrus Crops (CREA-OFA), Council for Agricultural Research and Economics, 0134 Rome, Italy; danilo.ceccarelli@crea.gov.it

* Correspondence: corrado.ciaccia@crea.gov.it; Tel.: +39-06-7005413

\begin{abstract}
The implementation of agroecology principles within organic farming research is a crux to redesign sustainable agri-food systems. To govern this transition, the local research demand should be addressed by direct engagement of all stakeholders in the research process. The first step is the involvement of farmers and technicians, with the aim of restoring their decision-making role, switching governance to local scale. The co-design/co-management of Long-Term Experiments (LTEs) can be crucial to govern the above-described transition through networking and participatory activities. In this study, we report the experience of co-designing a new LTE in Southern Italy by local actors and scientists. Through a participatory action research methodology, an LTE was considered as a biophysical component of an agroecological living lab, a public-private environment aimed to design a local food system. The setup of parallel field trials in satellite farms stands for the other biophysical component, whereas the stakeholder platform represents the social one. Through definition of common objectives, a step-by-step process is presented, which highlights the interest of local organic actors to share ideas and perspectives for the territory, pointing out the inclusion of end-users (the consumers) in the process to complete the transition to sustainable food systems.
\end{abstract}

Keywords: living lab; participatory action research; agroecology; organic agriculture; system redesign; long-term experiment

\section{Introduction}

Many authors have pointed out that the modern food systems are not sustainable from economic, social, and environmental perspectives [1-4]. Moreover, the COVID-19 crisis put in evidence all points of weakness of food systems at once: breakdown of supply chains, risks for workers, more hunger and malnutrition, and other problems from production through distribution to consumption [5]. As argued by some authors [6,7], it is the time to design and set up food systems more at the service of the right to food (food sovereignty), enhancing territoriality and control at the local level and aiming to reduce ecosystems degradation. However, the identification and implementation of more 
sustainable and appropriate agri-food models for a given context is a complex process, due to the multidimensional nature of sustainability and the presence of heterogeneous objectives [8]. Therefore, in governing such a transition, a true cost-accounting approach should be considered that encompasses the right of access to quality and healthy food, environmental protection and profit, and their stability over time [9]. By this, social and political engagement should be promoted, empowering marginalized actors, and farmers aimed at promoting collective action towards significant system changes [10]. This means that opening up spaces for autonomy and self-determination for stakeholders to engage in change and innovation offers a real possibility to create something different and feasible. This transformation process towards new people-centered sustainable systems needs a holistic approach that embrace a long-term vision, such as agroecology [11].

Despite its potential, narrow visions of agroecology are often presented and discussed [12], based on addressing environmental harms associated with industrial agriculture. Instead, according to Wezel [13], the concept of "ecology of the food system" should encompass all the three key components and their integration [10,13]: (i) an epistemological approach oriented to knowledge co-creation (agroecology as a science), (ii) the development of operational models able to harness and regenerate natural systems and processes (agroecology as practice), and (iii) a transformative perspective supporting rural communities, food sovereignty, social justice, local knowledge, and culture (agroecology as a movement). The co-creation and sharing of knowledge and practices is, then, a core element that drives decision-making in the agroecology approach, and the development of multi-actor networks is a favorable environment for these processes [10,11].

The first challenge is the restoration of the decision-making role of actors in the food system, as far as their willingness to cooperate and adhere to different views and goals $[10,14]$. To reach this objective, involving farmers primarily, as well as all the other actors engaged in agroecological practices, in research activities becomes crucial [10,15]. Moreover, recent policy documents [16] have stressed how context-related agroecological approaches, which value crop and farm diversification, as well as stakeholders' engagement, can improve sustainability of agricultural systems. In this context, systems integrating tree crops with perennial and annual herbaceous crops and/or livestock, in efficient vertical and horizontal as well as spatial and temporal combinations (agroforestry), have been identified as valuable options [17].

These systems can potentially optimize natural resources exploitation (improving nutrient and water cycling, soil quality, and carbon storage potential in different soil layers) and enhance farming productivity and profitability (maintaining crop yield by climate change adaptation, diversifying income, and, potentially, diet) $[17,18]$. In particular, the integration of agroforestry components in organic farms could represent a pathway for further development of organic agriculture towards increased sustainability. The multi-functionality of such systems can significantly contribute to the resilience of rural communities, both economically and socially, by delivering ecosystem services and promoting new value chains, due to broad range of products and recreational services [18].

Long-Term Experiments (LTEs) might play a crucial role by providing a safe place where changes can be played out and negotiated among a variety of interested actors. An LTE promotes transformation pathway of agri-food systems based on redesign, aiming to tackle the research priorities with local producers, representing a potential hub of common knowledge and innovation [19]. Moreover, the LTEs allow the long-term monitoring and assessment of the complex biological and ecological processes on which cropping system functioning is based on. Therefore, they represent an example of agroecological transition, tests of tools for assessing advances in agroecology, and food policy that puts forward the needed steps toward transformation [5]. Furthermore, when the LTEs involve parallel local farm-trials orbiting around the experiments (biophysical components), and other stakeholders engaged in decisional process and result evaluation (social component) through a participatory action research (PAR), they can be considered as agroecological living labs (ALL) [20]. 
In this paper, we report the experience of the AgroforSyLL (AGROFORestry SYstem Living Lab) setup initiative, carried out in Basilicata region (Southern Italy), through the involvement of farmers and other stakeholders following participatory research methods. We identified a framework based on two lines of redesign: (i) movement/governance scale, promoting farmers' decision-making power; and (ii) practice scale, co-projecting diversified sustainable agroforestry systems. The present work aimed at developing and activating a virtuous path of food-system redesign based on the continuous interaction and circular feedback-loop between a platform of organic actors and a multidisciplinary network of scientists. The general aim was to share goals and perspectives on a local scale, identifying solutions suitable for the territory.

\section{Materials and Methods}

A co-innovation process was implemented to activate the ALL and set up the LTE embedded with the actual research needs of the area in which the LTE is located, following the three phases described by Ciaccia et al. [14]: (1) identification both of the cultural broker and the network of actors (actor platform-AP); (2) definition of the objectives of common interest for researchers and AP to co-design the LTE; and (3) definition of the LTE layout and setting of parallel trials at satellite farms (the ALL definition). The activities started in 2019 and are still ongoing.

The described process was discussed and implemented at the experimental farm "Campo 7" of the Council for Agricultural Research and Economics (CREA), located in Metaponto (MT), Southern Italy (lat $40^{\circ} 24^{\prime} \mathrm{N}$; long $16^{\circ} 48^{\prime} \mathrm{E}$ and $8 \mathrm{~m}$ a.s.l.). The experimental farm is involved in organic and sustainable agriculture research for over 20 years; moreover, it is included in the Italian network of organic long-term experiments [19].

\subsection{The Local Context}

The Metaponto plain area-with a utilized agricultural area (UAA) of about 75,000 hais one of the most relevant productive area of the Basilicata region, particularly for vegetable production (mainly leafy vegetables, Cucurbitaceae and Brassicaceae). The area is also an important hub of strawberry and other fruit productions (e.g., apricot and orange). Organic production with 103,234 ha and 516 operators represents more than $20 \%$ of the total UAA in the Basilicata Region and about the $6 \%$ of the total producers are organic, with an increase of more than $2 \%$ and $3 \%$ in the $2018 / 2019$ period, respectively, in line with the national trend of $+2 \%$ for both organic area and operators in the same time span [21]. Organic farmers of the area, particularly small holders, are open to exchange opinions and solutions in participatory activities aimed at (i) meeting the growing demand for local products and (ii) getting an appropriate price for their products, considering production costs, and ensuring profit [14]. Diversification strategies (e.g., intercropping and agroforestry) are often considered as a valuable option to pursue both these final goals. In this context, CREA was interested in setting up a new LTE aimed at facing the research priorities for local organic farmers on vegetable production.

The climate of the Metaponto plain is classified as "accentuated thermomediterranean" according to the UNESCO-FAO classification [22], with mean monthly temperatures of $8.8^{\circ} \mathrm{C}$ in the winter and $24.4^{\circ} \mathrm{C}$ in the summer. The site is characterized by winter temperatures which can fall below $0{ }^{\circ} \mathrm{C}$, and summer temperatures which can rise above $40^{\circ} \mathrm{C}$. Rainfall (average $490 \mathrm{~mm}_{\text {year }}{ }^{-1}$ ) is unevenly distributed during the year and concentrated mainly in the winter months. The annual potential evaporation rate is high with a mean annual pan evaporation rate of $1549 \mathrm{~mm}$. In the last two decades, the area has been affected by the increased recurrence of flooding events during the rainy period (e.g., autumn), due to natural factors (soil characteristics), climate changes, and human activity [23]. In this climate change context, the research activities carried out in the last decade at the experimental farm focused on the assessment of the suitability of a set of agroecological techniques (e.g., soil hydraulic arrangement, crop rotations, agroecological service crops (ASCs) and their termination methods, and composting and organic fertilization) as poten- 
tial adaptation strategies for organic agroecosystems in Mediterranean environment [24,25]. The soil of the experimental farm is classified as a Typic Epiaquert [26]. It has a clay loam texture (60 and $36 \%$ of the clay and silt, respectively) with a soil bulk density of $1350 \mathrm{~kg} \mathrm{~m}^{-3}$, and it contains 1.0 and $19.0 \mathrm{~g} \mathrm{~kg}^{-1}$ of $\mathrm{N}$ and organic matter, respectively.

\subsection{The AgroforSyLL Experience}

Actions to move towards sustainability along a transformative pathway are managed according to a long-range, cyclical, self-correcting mechanism, following a simple fourstep model (plan, act, observe, and reflect, according to the Action Research Spiral [27]), for maintaining and enhancing the effectiveness of the results through self-analysis and self-renewal [28] (Figure 1). In other words, the pathways to transition are not set at the beginning and tested out and, hopefully, released as in a top-down approach, but, on the contrary, through participation, dialogue, and validation. To this end, a common direction is chosen by the confluence of different wills and interests.

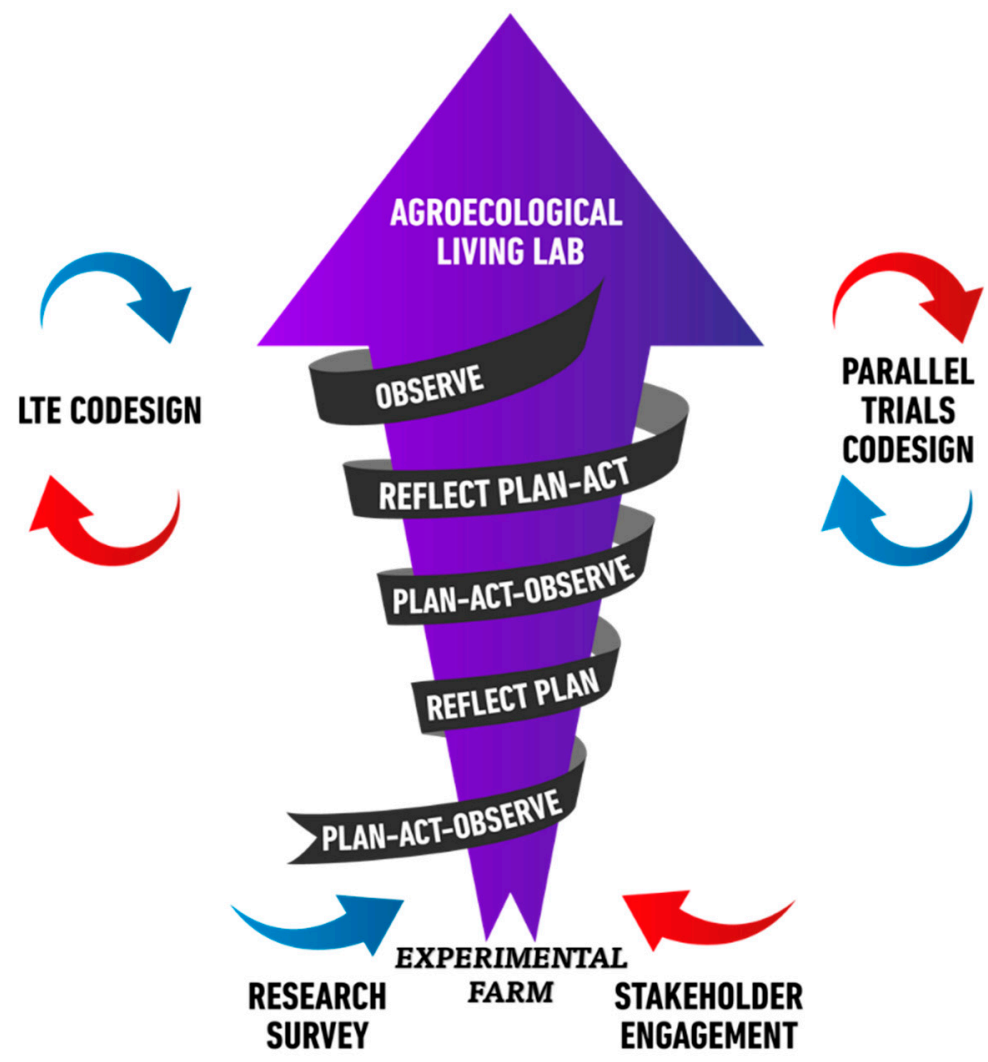

Figure 1. Logical framework of the methodology followed in AgroforSyLL setup and the followed trajectory of redesign through participatory activities and the engagement of scientists and food system actors.

A Participatory Action Research (PAR) methodological approach was used to collaborate with the local communities to reach a clear understanding of the role, assets and skills of researchers and other actors throughout the process of definition of a new LTE as ALL $[14,20,29,30]$. The ultimate goal was to create a research infrastructure (the ALL) embedded with the actual needs of agriculture in the Metaponto plain area. To do it, the degree of local actors' involvement in the formulation of the overall activity goals and in specific research topics for the LTE setup was decided, considering an evolution of their role and modes of interacting over time [10,14].

The three steps followed in the research process and the degree of participation are summarized in Figure 2. 


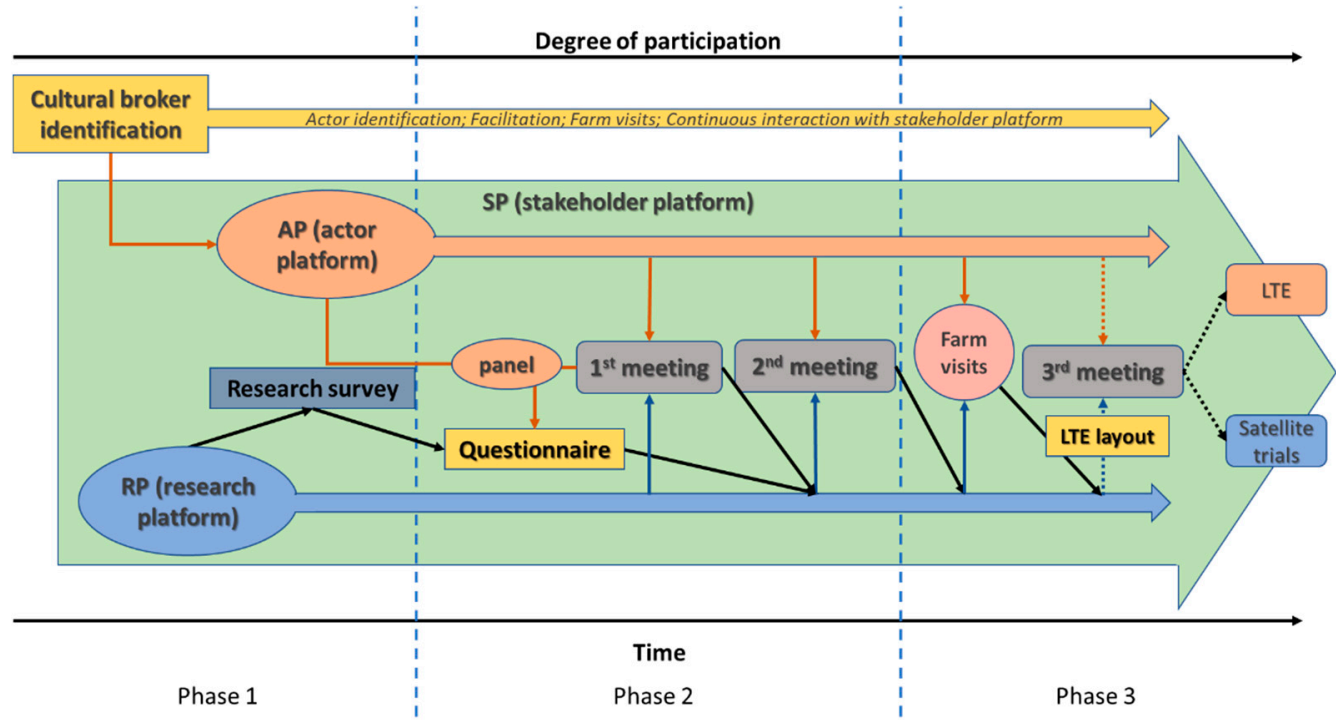

Figure 2. Visualization of Stakeholder Platform setup and interactions between components during the three phases.

\subsubsection{Phase 1: Identification of the Cultural Broker and Actor Platform Definition}

Functions of facilitation by expert stakeholders are crucial. The role of some actors (e.g., farmers, technicians, associations) as intermediary is recognized, indeed, to be a key aspect to support innovation processes, which progressively moved from a linear, topdown model to a network-based, bottom-up and systemic approach [31]. The identification of a cultural broker (i.e., the person who facilitates connection among groups of people of different cultural backgrounds [32]) is the first step for the definition of an Actor Platform (AP) and its objectives. The Agenzia Lucana di Sviluppo e di Innovazione in Agricoltura (ALSIA), a public institution working for support and innovation in agriculture, was identified at the beginning of the process as the cultural broker for its active role at the local level in researcher-local actor communication. ALSIA was asked to pinpoint local organic actors classifying them in accordance with (i) their potential interest in collaborating with a public research institute and (ii) their role as opinion leader in the area. ALSIA was asked to assign a value (1-10 scale) to potential participants; actors with a mean value higher than 6 were selected. Participation and active role at previous activities were also used for the identification of the local actors.

Besides the AP, a Research Platform (RP) was identified and composed by scientists interested in collaborating in the co-research and co-innovation process. Scientists were selected on the basis of previous collaborations with the experimental farm and to guarantee multidisciplinary to the process. The AP and the RP jointly represented the Stakeholder Platform (SP). The SP must be dynamic, allowing new stakeholders to join the network. A research survey was carried out to select the potential and broad research topics to be implemented in the new LTE and to be used to define research objectives of the ALL in phase 2. Each scientist of the RP was asked to identify a set of broad topics to be investigated in the studied areas, defining (i) the importance at the local scale, (ii) the relevance at the farm scale, and (iii) a feasibility analysis (in terms of digital/physical infrastructure needed, costs and time for their implementation, human works, and operative limits). Through a synthesis analysis of collected results, a selection of the main topics relevant for the Metaponto plain was identified and used as the starting point for the discussion with the AP.

\subsubsection{Phase 2: Research Demand and Main Criteria for LTE Setup}

In phase 2, a modified "participation by consultation" approach was followed [33], in which the AP was consulted with a questionnaire and iteratively by face-to-face meetings. The actors selected in phase 1 were invited to attend a first face-to-face meeting as the 
AP and a part of them (hereafter reported as "Panel") agreed also to participate in the questionnaire. Both the questionnaire and the first face-to-face meeting contributed to identify the research demand and the consequent objectives to be implemented in the ALL, starting from the broad topics selected through the research survey in phase 1.

The questionnaire, based on previous experiences in Italy [14,34] and on the main research topics identified by RP in the previous phase, was composed by 20 questions, including six open-ended and 14 closed-ended questions, the questionnaire was aimed to identify (i) the actor profile, (ii) the interest on the main topics and additional research demand for the local area, (iii) the personal visions about participatory research and previous experiences, and (iv) the willingness to join participatory activities. Five out six open-ended questions were nominal-polytomous questions [35], with five to seven unordered options and an open section in which it was asked to justify the previous choice and/or add additional options [34]. The 14 closed-ended questions were simply nominal-polytomous.

Since the organization of the first face-to-face meeting in May 2019 at the Metaponto experimental farm, actors were invited to join activities and discussions. Through an active listening approach, a communication technique in which the researcher verifies with the actors to ensure a correct and accurate understanding [36], the objectives of the meeting and the participants' research needs were discussed and deepened. The meeting has been devised to provide an active and safe space for collaboration: with more and less formal slot (e.g., proper meeting and farm visit) and breaking up in small groups to allow every participant to carve out comfortable way to contribute (i.e., Crowd Wise engagement method [37]), to then rearrange and recompose the input collected in a plenary session where contributions were debated, prioritized, and validated by the whole group.

Questionnaire results and workshop outputs were analyzed, and the synthesis with the selected topics to drive the LTE co-design was shared and discussed with the AP in a subsequent face-to-face meeting in October 2019 in the same site. Ideas, point of views, and suggestions were collected through a Crowd Wise workshop and used for the formulation of the new LTE implementing most of the research demands risen during this phase 2.

\subsubsection{Phase 3: Agroecological Living Lab Definition}

The last phase is characterized by a deepen interaction with the local actors through the organization of cyclical meetings with the AP, farm visits and direct researchers-local actors' communication. In this phase is crucial the direct interaction of the researchers with the cultural broker (ALSIA), to correct and fine tune the process of actors' involvement in the different activities.

Through the cultural broker, farm visit tours were organized in July 2020 and September 2020, to deepen the priorities of research raised during phase 2 and promote the participatory activity to enlarge the network.

Finally, this phase foresees the discussion with the AP of the LTE proposal drawn through the information and suggestions collected in phase 2 .

\section{Results}

\subsection{Stakeholder Platform Composition and Research Survey}

At the end of the phase 1 the SP was composed, through the selection of both AP and RP. ALSIA identified 44 potential actors and, by the stakeholder analysis, 22 of them were extracted and accepted to join the next activities as the AP. They were representative actors of the local area (i.e., farmers, technicians, advisors, and trade associations) and were engaged in the process, aiming to identify the research demand to be implemented. The RP was instead composed by nine scientists from CREA, covering different disciplines (agronomy, ecology, soil biology, and chemistry) and competences (i.e., agroecological practices, sustainability assessment, horticulture, carbon modeling, functional biodiversity, waste recycling, and participatory research), thus guaranteeing a multidisciplinary approach to the poll. 
Through the research survey, the poll identified four main broad topics to be investigated and discussed with local actors, namely (i) soil organic matter conservation/restoration (67\% of the poll indicated it as a priority to be investigated), (ii) climate change mitigation and adaptation (56\%), iii) diversification strategies for agroecosystems (56\%), and (iv) water-use optimization (22\%). For each topic, 5-7 subtopics were identified and included in the questionnaire shared in phase 2 with the selected panel within the AP and then discussed with the whole AP. The composition of the panel, the AP, and the RP composing the stakeholder platform are reported in Table 1 , and the interactions are summarized in Figure 2 .

Table 1. Composition of panel and stakeholder platform (actor and researcher platforms).

\begin{tabular}{ccccc}
\hline & & Panel & Actor Platform & Researcher Platform \\
\hline Number of participants & & 16 & 22 & $9^{1}$ \\
\hline \multirow{2}{*}{ Gender (n) } & Male & 15 & 21 & 5 \\
& Female & 1 & 1 & 4 \\
Age (n) & $18-39$ & 4 & 4 & 2 \\
& $40-59$ & 11 & 15 & 7 \\
& over 60 & 1 & 3 & - \\
Stakeholder profile $(\%){ }^{2}$ & Farmers & 81 & 68 & - \\
& Technicians & 50 & 50 & - \\
& Association & 19 & 23 & - \\
& Scientists & - & 8 & - \\
\hline
\end{tabular}

${ }^{1}$ Other two Scientists joint the RP after the second meeting in $2020 .{ }^{2}$ More than one option available to respondent.

\subsection{Questionnaire Analysis}

Main results of the questionnaire are reported in Figure 3 (interest to the main topics) and Figure 4 (vision about participatory activities). The panel recognized the overriding interest in the following: (i) the use of cover crops and soil amendments $(69 \%)$, the composting at the farm scale, and the waste recycling strategies ( $69 \%$ and $56 \%$, respectively) for soil organic matter conservation (Figure 3a); (ii) the use of perennial crops $(69 \%)$, hydraulic arrangements (56\%), and minimum tillage (44\%) as climate-change mitigation strategies (Figure 3b); (iii) the valorization of local varieties/landraces ( $81 \%$ ), the implementation of hedgerows and other ecological infrastructures (60\%), and the use of cover crops (53\%) as diversification strategies (Figure 3c); (iv) the use of intercropping ( $40 \%$ ), soil arrangements $(40 \%)$ and the use of automatization of management $(33 \%)$ for water use optimization (Figure 3d).

Individual vision and perceptions of the panel pointed out the participatory research as an opportunity (Figure 4a) to increase own knowledge on specific topics (75\%), to share own competence with other actors $(50 \%)$ and to connect local needs with research priorities $(50 \%)$. About expectations (Figure $4 \mathrm{~b}$ ), the panel identified participatory activities to set up a peer-to-peer experimental activity and data analysis $(75 \%)$, to obtain a more democratic research aimed to transdisciplinary goals (50\%) and to valorize farmers' knowledge (50\%). The panel considered the implementation of participatory research as positively impacting on (Figure $4 \mathrm{c}$ ) the promotion of sustainable practices $(88 \%)$, the revaluation of farmers' role in research (31\%) and the isolation often characterizing farmers' activity $(25 \%)$. Finally, the panel recognized the lack of incentives to farmers $(53 \%)$, the lack of common researchfarmer/technicians' language (31\%) and the lack of time (31\%) as the main constraints for the implementation of research activities (Figure $4 d$ ). 


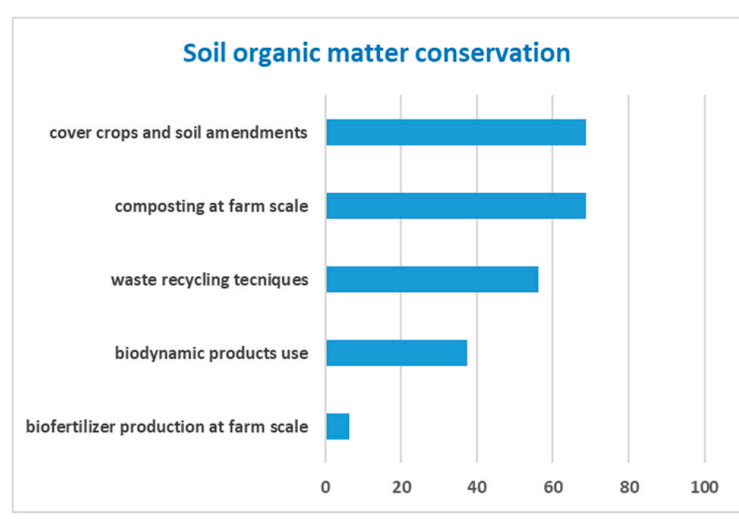

(a)

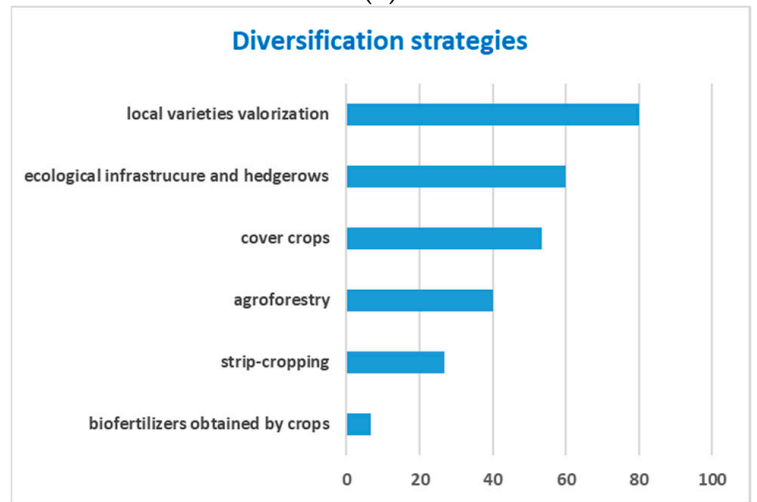

(c)

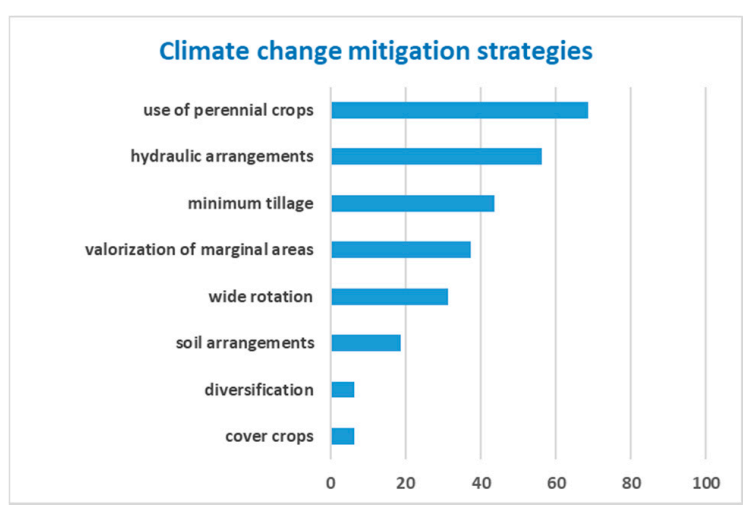

(b)

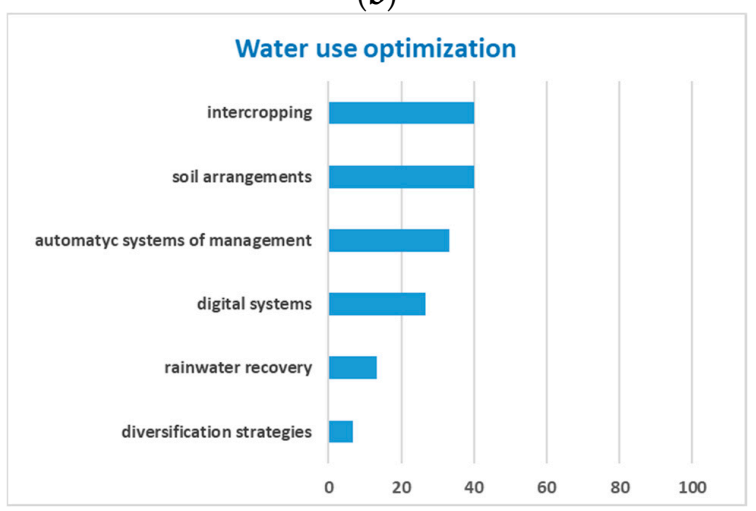

(d)

Figure 3. Results of questionnaire: (a) interest on subtopics of soil organic matter conservation; (b) climate change mitigation strategies; (c) diversification strategies; and (d) water-use optimization. Results are expressed as percentage of votes on the total participants $(n=16)$.

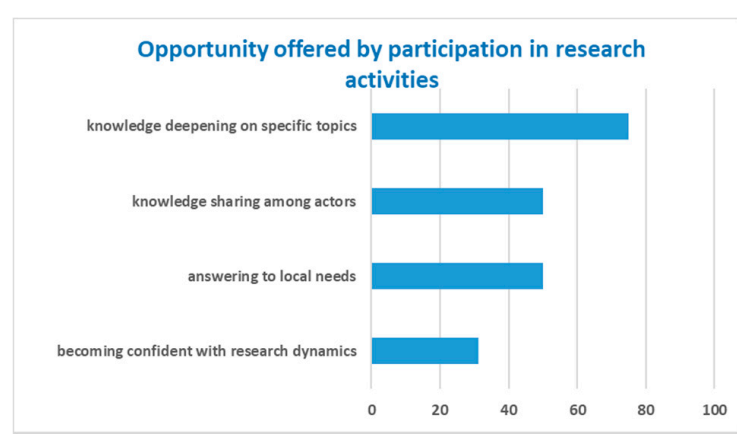

(a)

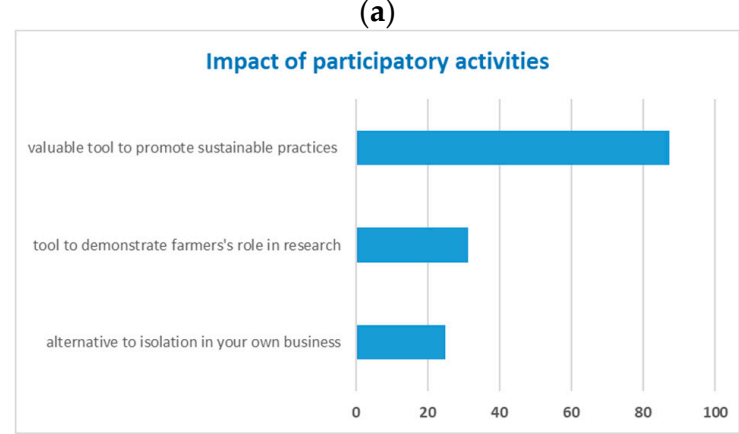

(c)

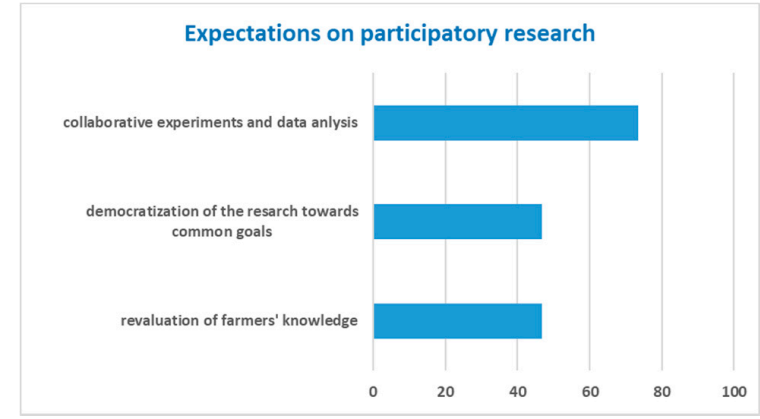

(b)

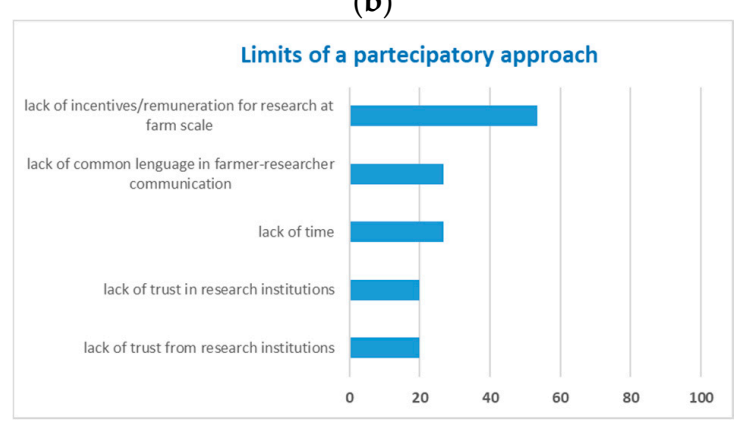

(d)

Figure 4. Results of questionnaire: (a) individual perception on the opportunity offered by participation; (b) expectations on participatory research; (c) perceived impact; and (d) limits of its implementation. Results are expressed as percentage of votes on the total participants $(n=16)$. 


\subsection{Workshop and Open Discussion Output}

During the first face-to-face meeting, the questionnaire results were discussed and validated. The AP confirmed the interest on the selected topics and the priorities pointed out by the panel, highlighting the crucial need to design a diversified rotation for the success of environmentally and economically sustainable organic vegetable systems. Furthermore, intercropping among vegetables and with perennial crops was recognized as an important strategy for both soil organic matter conservation and climate change mitigation. Similarly, the use of cover crops in the rotation was identified as a tool for soil organic matter restoration and as diversification strategy. The AP recognized the central role of local varieties/landraces, as well as the cultivation of heterogeneous materials (i.e., genetically diverse plant individuals of the same crop species obtained by the Evolutionary Plant Breeding Program based on the combined effect of natural and artificial selection acting on heterogeneous populations [38]) as an opportunity for adaptation to climate change, wateruse optimization, tolerance to pest diseases, and as economically relevant diversification practice. The AP underlined how all the proposed and discussed re-design practices might be associated to a parallel analysis of the opportunity offered by the market, analysing alternative to short-chain and carrying out research activities able to upscale from the farm context. Therefore, the AP identified the consumer awareness and education as additional main topic and expressed the need to enlarge the platform encompassing economic competences.

\subsection{Second Face-to-Face Meeting and Criteria Selection}

According to the action research spiral, based on the results collected from the panel and the AP, the following topics were selected to drive the LTE co-design: (i) soil and hydraulic arrangements; (ii) cover crop, soil amendment, and composting implementation; (iii) introduction of fruit tree crops as redesign strategy in horticultural systems (agroforestry); (iv) diversification practices of horticultural systems; (v) innovation on system management; (vi) open-pollinated and local vegetable varieties/landraces introduction; and (vii) simplified sustainable analysis of the proposed systems.

In the second face-to-face meeting, the AP was asked to give individual and collective opinions on some topics, in particular (a) interest on agroforestry system and suggested fruit crop species, (b) which diversification strategy besides introduction of perennial crops to be implemented, (c) which management strategy should have priority in research, (d) which local varieties should be rescued/used, and (e) any other overriding topic to be investigated. In addition, with the aim of facing the AP requests risen at the previous meeting, an expert on the field of agricultural economics was invited to the meeting and actively participated in open discussion, together with the other scientists of the RP involved in the process. The AP highlighted great interest in the introduction of fruit crops as diversification strategy in horticultural systems, suggesting the introduction of this component as alley crop within the field. The proposed fruit species and the main comments are reported in Table 2.

The AP showed interest for species with multiple production attitudes (fresh, dry, and/or processed products), preferring those typical of the area. Besides fruit crops, the introduction of agroecological infrastructures was recognized as one of the priority diversification strategy. In particular, the introduction of hedgerows projected considering both the ecological services provision and the potential recycling of pruning residues within farm boarder was discussed. Among management practices, on the one hand, the use of cover crops and intercropping was indicated as the most promising strategy for soil organic matter and water management; on the other hand, soil/hydraulic arrangements through ridge-furrow system were considered to support the introduction of perennial crops as adaptation strategy to climate change and flooding. The introduction of heterogeneous materials, as far as the use of local varieties, was extensively discussed, pointing out the relevance of their introduction and rescue to meet the growing demand of such products in local and gross distribution markets. Finally, the strategies for accessing the market and 
the identification of new opportunities for products derived from diversified systems (e.g., through market analysis) were carefully analyzed (data not reported).

Table 2. Result of the second face-to-face meeting: perennial crops and the opportunities for the territory offered by their introduction.

\begin{tabular}{|c|c|c|c|}
\hline Species & Market Opportunities & Notes & $\begin{array}{l}\text { Diffusion at } \\
\text { Local Scale }\end{array}$ \\
\hline Diospyros kaki (L.) & Fresh and processed products & $\begin{array}{l}\text { Needs for post-harvest organization. } \\
\text { Interest towards non astringent cultivar }\end{array}$ & $x$ \\
\hline Ficus carica (L.) & $\begin{array}{l}\text { Growing interest in fresh product in } \\
\text { Central Europe and lack of organic } \\
\text { production of dry fruits }\end{array}$ & $\begin{array}{l}\text { Cultivation was widespread until the } \\
\text { 1950s. Currently, there are a few } \\
\text { specialized organic farms in the area }\end{array}$ & $x$ \\
\hline Malus domestica (Borch.) & $\begin{array}{l}\text { Interest in local varieties, answering } \\
\text { to a growing demand of } \\
\text { these products }\end{array}$ & $\begin{array}{l}\text { The crop is not widespread in the plains } \\
\text { due to its high chilling requirement }\end{array}$ & \\
\hline $\begin{array}{l}\text { Morus alba (L.); } \\
\text { M. nigra (L.) }\end{array}$ & $\begin{array}{l}\text { Interest for fresh product, } \\
\text { opportunity offered by sericulture }\end{array}$ & $\begin{array}{l}\text { In traditional farm, few plants were } \\
\text { common. It can provide valuable } \\
\text { materials for composting } \\
\text { (pruning residues) }\end{array}$ & \\
\hline Opuntia ficus-indica (L.) & Interest in organic fresh production & $\begin{array}{l}\text { Naturalized species, it is commonly used } \\
\text { also in the hedgerows }\end{array}$ & $x$ \\
\hline Pistacia vera (L.) & $\begin{array}{l}\text { Growing demand for } \\
\text { processed product }\end{array}$ & $\begin{array}{l}\text { Suitable for intensive systems thank to } \\
\text { high mechanization level of harvest }\end{array}$ & \\
\hline Prunus dulcis (Mill.) & Interest in organic processed products & $\begin{array}{c}\text { Suitable for intensive systems thank to } \\
\text { high mechanization level of pruning } \\
\text { and harvest }\end{array}$ & $x$ \\
\hline Punica granatum (L.) & Fresh and processed products & $\begin{array}{l}\text { Widely cultivated on the Ionian coast, } \\
\text { presence of organic specialized farms for } \\
\text { juice production }\end{array}$ & $X$ \\
\hline Pyrus communis (L.) & $\begin{array}{l}\text { Interest in local varieties, answering } \\
\text { to a growing demand of } \\
\text { these products }\end{array}$ & $\begin{array}{l}\text { The crop is not widespread in the plains } \\
\text { due to its high chilling requirement }\end{array}$ & \\
\hline Berry fruits & $\begin{array}{l}\text { Interest in connecting their } \\
\text { production with the distribution } \\
\text { chain of strawberry }\end{array}$ & $\begin{array}{l}\text { In the area, strawberry is widespread also } \\
\text { in rotation with vegetable crops }\end{array}$ & \\
\hline Officinal plants & Growing demand of dry products & Presence of organic producers in the area & $x$ \\
\hline
\end{tabular}

\subsection{The Biophysical Component: The LTE Proposal}

The new LTE design was based on a hydraulic arrangement able to protect crops from flooding in the case of heavy rainfall events. It consisted in the realization of a bedding systems with channels separating the raised beds that are $24 \mathrm{~m}$ wide and $60 \mathrm{~m}$ long. The raised beds should be realized through ploughing, guaranteeing a difference of $0.5 \mathrm{~m}$ height between the center of the bed and channel, respectively. On each bed, a different vegetable production system should be implemented, for a total of three different systems repeated three times in a three-blocks layout (Figure 5).

A perimetral $9 \mathrm{~m}$-wide hedgerow should be planted to separate the new LTE from the surrounding environments external to experimental farm boarder. Internal hedgerows ( $4 \mathrm{~m}$ wide) were projected to separate the three blocks. Perimetral and internal hedgerows should differ in species composition to increase the diversification and ecosystem services provided, trying to limit the shading effect of introduced plants on the cropping systems. The three compared systems were based on a four-year vegetable rotation with introduction of Agroecological Service Crops (e.g., cover crops and living mulches), as well as 
local varieties/landraces, and each system should be divided into four $5 \mathrm{~m}$-wide strips, corresponding to the four rotative years.

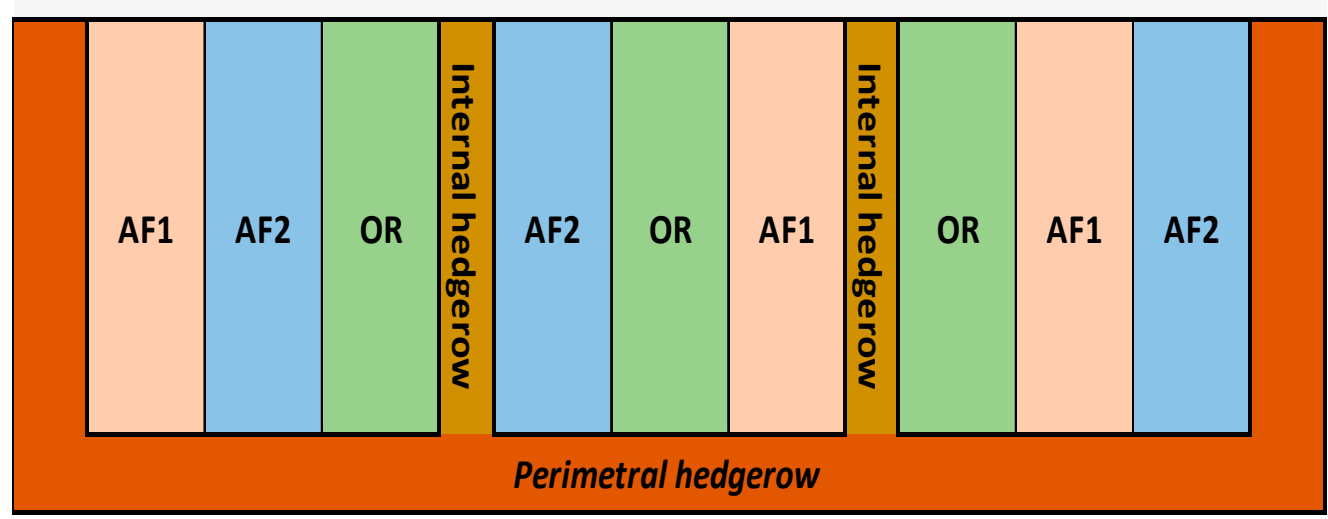

(a)

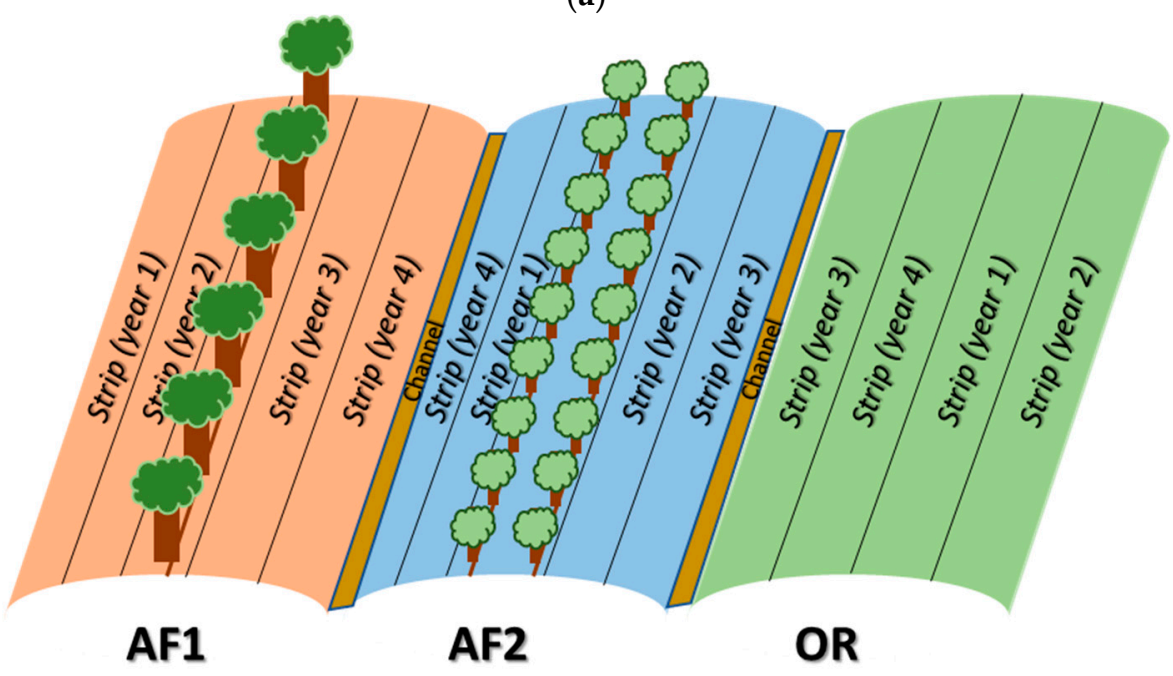

(b)

Figure 5. The LTE layout proposed based on the results in phase 1 and 2: (a) layout and (b) detail of one block.

The systems should be organized as follow: (i) AF1, a central alley of two rows of shrub/bush crops separating the four rotative area into two groups (Agroforestry System 1); (ii) AF2, a central alley of one row of fruit crop separating the four rotative area into two groups (Agroforestry System 2); and (iii) OR, organic rotation systems.

Once the introduction of Agroforestry systems raised as an option, the RP was enlarged to other CREA scientists with expertise on fruit-crop management, selection, and physiology, to identify the perennial crops suitable for the specific pedoclimatic conditions of the experimental area. Based on the AP suggestions (Table 2), different hypotheses were evaluated, considering both the risk of direct competition with the intercropped vegetables and the workload requested for crop management (compatibility with the vegetable crop rotation). The pros and the cons of the most suitable options were analyzed and discussed within the RP (Table 3). 
Table 3. Advantages and disadvantages of principal solutions for agroforestry systems in the LTE.

\begin{tabular}{|c|c|c|c|}
\hline LTE System & Crop & Pros & Cons \\
\hline AF1 & Persimmon & $\begin{array}{l}\text { Availability of local varieties. Constant } \\
\text { and high production }\end{array}$ & $\begin{array}{c}\text { Large root systems, able to explore up to } 5 \mathrm{~m} \\
\text { from the trunk. Needs for post-harvest } \\
\text { organization. Fly protection }\end{array}$ \\
\hline AF1 & Fig & $\begin{array}{l}\text { Production after } 2 \text { to } 3 \text { years from } \\
\text { planting. Possibility to reduce the height } \\
\text { of brunches and to obtain two crops' } \\
\text { branches. Few pests }\end{array}$ & $\begin{array}{c}\text { Extensive root systems in case of reduced } \\
\text { water availability. Increase in alien } \\
\text { pest diseases }\end{array}$ \\
\hline AF2 & Blackberry & $\begin{array}{l}\text { Low workload requested; high } \\
\text { product value }\end{array}$ & $\begin{array}{l}\text { Initial investment for training system } \\
\text { materials (V-shape) }\end{array}$ \\
\hline AF2 & Red Raspberry & $\begin{array}{l}\text { Availability of primocane-fruiting } \\
\text { (double production) low chilling } \\
\text { cultivars. Lack of production in the area }\end{array}$ & $\begin{array}{l}\text { Subacid soil; suggested shading systems; } \\
\text { daily harvest for long period }\end{array}$ \\
\hline AF2 & Officinal plants & Satisfying market request & $\begin{array}{l}\text { Limited knowledge on their } \\
\text { agronomic needs }\end{array}$ \\
\hline
\end{tabular}

The fig tree was identified as being suitable for the AF1 system, whereas the blackberry and officinal plants were chosen for the AF2 one. The farm visits in phase 3 were then organized to (i) collect information about market limits and opportunities for the fig crop, (ii) identify specific research demand for fig crop, and (iii) observe and note the cropped fig varieties. They interested seven different organic farms with a relevant production of fig crop, as well as the ALSIA germplasm collection. Based on the farm visits, the following aspects were identified as priority research and considered for the LTE and parallel trials projecting (a) trees training system solutions and (b) fruit-processing techniques for organic systems. Finally, a list of international, national, and local varieties responding to the production needs risen during the visits was identified and shared with the AP during phase 3.

\section{Discussion}

Our participatory research experience has shown a strong interest of local actors in joining all the activities, expressing the will to find answers to their needs in terms of innovation and perspectives. In their study of perceived benefits of ecological intensification between scientists and farmers, Kleijn et al. [39] report a little interest of European farmers in ecological practices, generally preferring those ones that interfere little with normal farming operations. In contrast with this statement, the interviewed panel expressed the idea of participatory research as a tool to widely spread sustainable practices (Figure $4 \mathrm{c}$ ), proposing use of perennials, intercropping, and soil/hydraulic arrangements as solutions for the discussed topics (Figure 3). This different outcome can be explained by the peculiar composition of our panel, made up only by actors of organic systems, generally characterized by high dynamism and aptitude to exchange experiences in participatory activities [14,40]. Regarding constraints limiting participatory research (Figure 4d), the lack of full support by institutions was the key one confirming the result of Delate et al. [34]. This limit is due to the lack of explicit demands request of on-farm trials within the grant requirements released by Italian funding agencies, despite the involvement of real farms and farmers being strongly promoted for research projects. The aspects related to opportunity costs for scientists and farmers were highly debated and should be considered, depending on the level of desired involvement and the final objectives of the co-research activities [41]. With the final goal to activate a system redesign process, the involvement of local actors should be high; by this, the final decision of the SP was to promote the participation also through the release of some incentives. Among them, the fruit crops provision to farms hosting the parallel trials, in accordance with a "participation for material incentives" approach was planned [32]. The "lack of time" cited together with "lack of common language" as 
the second most important constraint factor is strictly connected with the previous aspect of financing. Indeed, Hoffman et al. [41] underlines how opportunity costs should be respected if farmers dedicate time to research. The perceived "lack of common language" highlighted the difficulties in communication among different stakeholders, pointing out the role of facilitation in enabling conditions for collaborative learning [10].

Qualitative results obtained during face-to-face meetings showed interest and concerns about the introduction of perennial crops in vegetable systems. Interest was mainly related to the benefits derived by diversification of horticultural cropping systems, allowing (i) the production of more per unit area and more sustainably [18] and (ii) the reduction of the economic damage in the case of extreme climatic event like flooding [42]. Constraints were mainly related to work organization and competition between agricultural practices and between crops. For this reason, the AP pointed out alley system as the agroforestry system to be studied. This result confirms what reported by Camilli et al. [43] about the perception of stakeholders on agroforestry introduction effects, being generally positive on production and the environment, but negative on management.

The interviewees indicated the introduction in the rotation of ASCs and use of soil amendments (by composting and other waste-recycling strategies) as preferred practices for soil organic matter restoration and conservation (Figure 4a). They highlighted an interest in strategies able to maximize nutrient turnover within the farm border, in a circular dimension typical of closed-loops model [25,44]. Similarly, also the introduction of ecological infrastructures as hedgerows (Figure 4c) was considered in a functional perspective for on-farm recycling, since the AP pointed out the role of using their vegetable residues in composting processes (e.g., hedgerows' pruning residues) more than for related ecosystems and landscape benefits. This result is in line with the study of Fantappié et al. [45] on farmers' perception of soil conservation practices in Western Sicily. The panel and the AP put a strong interest in the introduction of local varieties/landraces (Figure 4c, both the face-to-face meetings), pointing out the bond of local actors with their own cultural heritage in contrast with crop uniformity of modern agriculture. This is a common aspect in the Italian agriculture, especially for small farms in Southern Italy and reflected by the large use and request by the population for locally adapted vegetable varieties [46,47]. The use of wide rotation was reported as basic diversification strategy, in accordance with previous studies [39].

Among the abovementioned (Table 3) fruit tree crops, the use of both traditional species, such as the fig and the persimmon, as well as alternative berry crops, represent an opportunity for farmers to significantly enlarge the ripening calendar, from mid-April (spring) until December (winter). Moreover, fig and berry productions allow the opportunity for growers to promote also dried and transformed productions. In the case of figs, it is important to highlight the diffusion of new pest diseases in Italy for the species [48]; therefore, the choice of the cultivars should consider local genotypes well adapted to the area. The new trends observed in the studied area for the training system need knowledge on the reproductive habitus of the species and represent a key factor to improve the harvest-season length and guarantee high fruit-qualitative standards [49]. For berry crops-for the red raspberry, in particular-the cultivars should be chosen among the primocane-fruiting group. These cultivars are well adapted for Mediterranean and coastal areas since they have a lower chilling requirement compared to the floricane cultivars [50]. The red raspberry primocane fruiting, moreover, can guarantee the possibility to obtain two productions, by using different training forms for a wide commercialization period.

\section{Next Steps and AGROFORSYLL Perspectives}

Due to the policies restricting people's movement during the pandemic and the need to rearrange activities on web-basis phase 3 is still ongoing.

To definitively confirm the LTE design and implement the proposed solutions in the experimental farm, a new meeting is going to be organized with the AP. Once the LTE proposal will have satisfied the stakeholder platform's ideas, needs and objectives, by the 
final acceptance of the design and implemented topics, new challenges, and new steps to be followed will raise. They might be mainly related to (i) LTE monitoring and management (e.g., local varieties/landraces to be tested in the proposed systems, relevant indicators selection, etc.); and (ii) actor platform empowerment and enlargement. LTE monitoring should then pursue and analyze the topic implemented, studying the compared system on agronomic, biochemical, and agronomic aspect, evaluating the solutions in the context of adaptation to climate changes. Moreover, with the aim to verify the sustainability of the analyzed systems, an ex post Multi-Criteria Analysis (MCA) will be implemented and adopted. The MCA will consider and evaluate, together, all three aspects of the sustainability (economic, environmental, and social), allowing us to analyze the consequences and the impact of many different conservation agriculture management strategies simultaneously and their synergistic approach on the systems.

The AP should be enlarged by inviting new actors selected by ALSIA and identified during the activities carried out during phase 2 , finally defining the social dimension of the ALL. This improvement should be done following a higher gender balance in the AP, still not representative of the role of women in agriculture in the Basilicata Region (35\% of farms and enterprise in agriculture are managed by women [51]) and due to a scarce participation in the activities carried out in previous experiences. Comments, suggested changes and point of views might be then integrated in an LTE co-design perspective. By face-to-face or web meeting, the willingness of AP farmers to set up parallel trials on the same topics will be discussed, starting a new process of re-definition of the satellite farms composing the agroecological living lab biophysical dimension [52]. The implementation of research topics in parallel field trials of the satellite farms (AP network) allows us to move from the field to farm scale and maximize the impact of the activities to a territorial/local one [19]. The LTE-satellite farms connection should be a valuable tool for bridging the gap between science and practice, satisfying both the needs of farmers and other value chains operators (more dynamic, interested to profits and market evolution), and researchers (more static, interested in slow-evolution processes) [39].

Finally, the already carried out workshops and open discussions raised the need of involved actors to upscale from the field and the farm contexts, finding in consumers and policy makers involvement the recognized strategy for an effective system redesign towards and agroecological territory definition, as reported by several authors $[5,7,11,28]$. Further activities should then encompass the engagement of these actors in the network, by the implementation of the correct methodology in the process [53]. Therefore, in this process, the three major domains for the agroecological transition take place, namely (i) adaptation of agricultural practices, (ii) conservation of biodiversity (including traditional cultivar valorization) and natural resources, and (iii) development of embedded food systems, so defining the ALL as an Agroecological Territory [54].

Author Contributions: Conceptualization, C.C.; data curation, C.C., E.T., A.F. and M.D.; formal analysis, C.C.; funding acquisition, D.C. and M.D.; investigation, C.C., E.T., I.I., S.C. and M.D.; methodology, C.C., M.D.P., E.T., F.F., M.C., I.I., A.P., S.C. and M.D.; project administration, D.C. and M.D.; supervision, D.C.; visualization, C.C.; writing-original draft, C.C., I.I., A.P. and S.C.; writing-review and editing, E.T., M.D.P., G.M., F.F., M.C., F.M., R.F., D.C. and M.D. All authors have read and agreed to the published version of the manuscript.

Funding: This research was funded by the PERILBIO (Promotion and strengthening of long-term experiments in organic agriculture) and the RETIBIO2 (Support activities for research networks in organic farming) research projects funded by the "Organic farming" Office, DG-PQAI I-Italian Ministry of Agriculture (Mipaaf), in the frame of the National Action Plan for Organic food and farming.

Institutional Review Board Statement: Not applicable.

Informed Consent Statement: Informed consent was obtained from all subjects involved in the study.

Data Availability Statement: Not applicable. 
Acknowledgments: The authors wish to thank Alberto Marchi for his help in the graphic (Figure 1) and to Marco Favale, Francesco Rinaldi, Angelo Quaranta, Rosalba Scazzariello and Giuseppe Dell'Orco for their active support in meetings and field days' organization. Special thanks to all the farmers, technicians, associations, scientists, and others participant in the AgroforSyLL experience.

Conflicts of Interest: The authors declare no conflict of interest. The funders had no role in the design of the study; in the collection, analyses, or interpretation of data; in the writing of the manuscript; or in the decision to publish the results.

\section{References}

1. Food and Agriculture Organization of the United Nations (FAO). The Future of Food and Agriculture-Trends and Challenges; FAO: Rome, Italy, 2017.

2. The International Panel of Experts on Sustainable Food Systems (IPES-Food). From Uniformity to Diversity: A Paradigm Shift from Industrial Agriculture to Diversified Agroecological Systems. In International Panel of Experts on Sustainable Food Systems; IPES-Food: Brussels, Belgium, 2016. Available online: www.ipes-food.org/img/upload/files/UniformityToDiversity_FULL.pdf (accessed on 27 October 2020).

3. Béné, C.; Oosterveer, P.; Lamotte, L.; Brouwer, I.D.; de Haan, S.; Prager, S.D.; Talsma, E.F.; Khoury, C.K. When food systems meet sustainability-Current narratives and implications for actions. World Dev. 2019, 113, 116-130. [CrossRef]

4. Kremen, C.; Iles, A.; Bacon, C. Diversified Farming Systems: An Agroecological, Systems-based Alternative to Modern Industrial Agriculture. Ecol. Soc. 2012, 17, 44. [CrossRef]

5. Gliessman, S.R. Transforming food and agriculture systems with agroecology. Agric. Hum. Values 2020, 37, 547-548. [CrossRef] [PubMed]

6. Anderson, F. Food Sovereignty Now! EUROPEAN Coordination via Campesina. 2018. Available online: https://viacampesina. org/en/wp-content/uploads/sites/2/2018/02/Food-Sovereignty-A-guide-Low-Res-Vresion.pdf (accessed on 27 October 2020).

7. Loker, A.; Francis, C. Commentary: Urban food sovereignty: Urgent need for agroecology and systems thinking in a post-Covid 19 future. Agroecol. Sustain. Food Syst. 2020, 44, 1118-1123. [CrossRef]

8. Mottet, A.; Bicksler, A.; Lucantoni, D.; De Rosa, F.; Scherf, B.; Scopel, E.; López-Ridaura, S.; Gemmil-Herren, B.; Kerr, R.B.; Sourisseau, J.-M.; et al. Assessing Transitions to Sustainable Agricultural and Food Systems: A Tool for Agroecology Performance Evaluation (TAPE). Front. Sustain. Food Syst. 2020, 4, 579154. [CrossRef]

9. Aspenson, A. True Costs for Food System Reform: An Overview of True Cost Accounting Literature and Initiatives; Center for a Livable Future (CLF), Johns Hopkins Bloomberg School of Public Health: Baltimore, MD, USA, 2020; p. 24.

10. Rossi, A. From Co-Learning to Shared Commitment to Agroecology. Some Insights from Initiatives Aimed at Reintroducing Agrobiodiversity. Sustainability 2020, 12, 7766. [CrossRef]

11. Barrios, E.; Gemmill-Herren, B.; Bicksler, A.; Siliprandi, E.; Brathwaite, R.; Moller, S.; Batello, C.; Tittonell, P. The 10 Elements of Agroecology: Enabling transitions towards sustainable agriculture and food systems through visual narratives. Ecosyst. People 2020, 16, 230-247. [CrossRef]

12. Alonso-Fradejas, A.; Forero, L.F.; Ortega-Espès, D.; Drago, M.; Chandrasekaran, K. 'Junk Agroecology': The corporate Capture of Agroecology for a Partial Ecological Transition without Social Justice. 2020. ATI, TNI, Crocevia. Available online: https://www. foei.org/wp-content/uploads/2020/10/Junk-Agroecology-FOEI-TNI-Crocevia-report-ENG.pdf (accessed on 27 October 2020).

13. Wezel, A.; Bellon, S.; Dore, T.; Francis, C.; Vallod, D.; De David, C. Agroecology as a science, a movement and a practice. A review. Agron. Sustain. Dev. 2009, 29, 503-515. [CrossRef]

14. Ciaccia, C.; Di Pierro, M.; Testani, E.; Roccuzzo, G.; Cutuli, M.; Ceccarelli, D. Participatory Research towards Food System Redesign: Italian Case Study and Perspectives. Sustainability 2019, 11, 7138. [CrossRef]

15. Lacombe, C.; Couix, N.; Hazard, L. Designing agroecological farming systems with farmers: A review. Agric. Syst. 2018, 165, 208-220. [CrossRef]

16. High Lecel Panel of Experts (HLPE). Agroecological and Other Innovative Approaches for Sustainable Agriculture and Food Systems that Enhance Food Security and Nutrition; HLPE: Rome, Italy, 2019.

17. Mosquera-Losada, M.; Santiago-Freijanes, J.; Rois-Díaz, M.; Moreno, G.; Herder, M.D.; Aldrey-Vázquez, J.; Ferreiro-Domínguez, N.; Pantera, A.; Pisanelli, A.; Rigueiro-Rodríguez, A. Agroforestry in Europe: A land management policy tool to combat climate change. Land Use Policy 2018, 78, 603-613. [CrossRef]

18. Rosati, A.; Borek, R.; Canali, S. Agroforestry and organic agriculture. Agrofor. Syst. 2020, 1-17. [CrossRef]

19. Ciaccia, C.; Ceccarelli, D.; Antichi, D.; Canali, S. Long-term experiments on agroecology and organic farming: The Italian long-term experiment network. In Long-Term Farming Systems Research; Elsevier: Amsterdam, The Netherlands, 2020; pp. 183-196.

20. MACS-G20 (Meetings of Agricultural Chief Scientists of G20 States). Agroecosystem Living Laboratories. Executive Report. 2019. Available online: http:/ / www.macs-g20.org (accessed on 5 November 2020).

21. SINAB (Sistema Informativo Nazionale Agricoltura Biologica). Italian National Organic Agriculture Statistics; Bio in cifre 2020; Sistema Informativo Nazionale Agricoltura Biologica: Rome, Italy, 2020. Available online: http:/ /www.sinab.it/ (accessed on 15 November 2020). (In Italian) 
22. UNESCO-FAO. Bioclimatic Map of the Mediterranean Zone; NS162/III, 22A; UNESCO: Paris, France; FAO: Rome, Italy, 1963 ; p. 60.

23. Bentivenga, M.; Giano, S.I.; Piccarreta, M. Recent Increase of Flood Frequency in the Ionian Belt of Basilicata Region, Southern Italy: Human or Climatic Changes? Water 2020, 12, 2062. [CrossRef]

24. Diacono, M.; Fiore, A.; Farina, R.; Canali, S.; Di Bene, C.; Testani, E.; Montemurro, F. Combined agro-ecological strategies for adaptation of organic horticultural systems to climate change in Mediterranean environment. Ital. J. Agron. 2016, 11, 85-91. [CrossRef]

25. Diacono, M.; Persiani, A.; Testani, E.; Montemurro, F.; Ciaccia, C. Recycling Agricultural Wastes and By-products in Organic Farming: Biofertilizer Production, Yield Performance and Carbon Footprint Analysis. Sustainability 2019, 11, 3824. [CrossRef]

26. USDA-NRCS. Soil Taxonomy, A Basic System of Soil Classification for Making and Interpreting Soil Surveys; Agriculture Handbook 436; USDA-NRCS: Washington, DC, USA, 1999.

27. Kemmis, S.; McTaggart, R. Participatory Action Research: Communicative Action and the Public Sphere. In The Sage Handbook of Qualitative Research; Denzin, N.K., Lincoln, Y.S., Eds.; Sage Publications Ltd.: Thousand Oaks, CA, USA, 2005 ; pp. 559-603.

28. O'Brien, R. Um Exame da Abordagem Metodológica da Pesquisa Ação [An Overview of the Methodological Approach of Action Research]. In Teoria e Prática da Pesquisa Ação [Theory and Practice of Action Research]; English Version; Richardson, R., Ed.; Universidade Federal da Paraíba: João Pessoa, Brazil, 2001. Available online: http://www.web.ca/ \{\}robrien/papers/arfinal. html (accessed on 14 November 2020).

29. Neef, A.; Neubert, D. Stakeholder participation in agricultural research projects: A conceptual framework for reflection and decision-making. Agric. Hum. Values 2010, 28, 179-194. [CrossRef]

30. Van de Fliert, E.; Braun, A.R. Conceptualizing integrative, farmer participatory research for sustainable agriculture: From opportunities to impact. Agric. Hum. Values 2002, 19, 25-38. [CrossRef]

31. Kivimaa, P.; Hyysalo, S.; Boon, W.; Klerkx, L.; Martiskainen, M.; Schot, J. Passing the baton: How intermediaries advance sustainability transitions in different phases. Environ. Innov. Soc. Transit. 2019, 31, 110-125. [CrossRef]

32. Jezewski, M.A.; Sotnik, P. The Rehabilitation Service Provider as Culture Broker: Providing Culturally Competent Services to Foreign Born Persons; Center for International Rehabilitation Research Information and Exchange: Buffalo, NY, USA, 2001.

33. Pimbert, M. Participatory Research and On-Farm Management of Agricultural Biodiversity in Europe; Pimbert, M., Ed.; International Institute for Environment and Development (IIED): London, UK, 2011; p. 80.

34. Delate, K.; Canali, S.; Turnbull, R.; Tan, R.; Colombo, L. Participatory organic research in the USA and Italy: Across a continuum of farmer-researcher partnerships. Renew. Agric. Food Syst. 2016, 32, 331-348. [CrossRef]

35. Gillham, B. Developing a Questionnaire, 2nd ed.; Continuum International Publishing Group Ltd.: London, UK, 2008.

36. Guion, L.A.; Diehl, D.C.; McDonald, D. Conducting an In-Depth Interview; University of Florida Cooperative Extension Service, Institute of Food and Agricultural Sciences EDIS: Gainesville, FL, USA, 2001.

37. Chonkova, B. Crowd Wise. In D3.2 Public Engagement Methods and Tools; Report of “Engage 2020, Tools and instruments for a better societal engagement in Horizon 2020"; 2014; pp. 49-51. Available online: http://engage2020.eu/media/Fact-sheet-on-thecurrent-praxis-of-methods-tools-and-instruments.pdf (accessed on 14 November 2020).

38. Raggi, L.; Ciancaleoni, S.; Torricelli, R.; Terzi, V.; Ceccarelli, S.; Negri, V. Evolutionary breeding for sustainable agriculture: Selection and multi-environmental evaluation of barley populations and lines. Field Crop. Res. 2017, 204, 76-88. [CrossRef]

39. Kleijn, D.; Bommarco, R.; Fijen, T.P.; Garibaldi, L.A.; Potts, S.G.; van der Putten, W.H. Ecological Intensification: Bridging the Gap between Science and Practice. Trends Ecol. Evol. 2019, 34, 154-166. [CrossRef] [PubMed]

40. Silva, E.; Hendrickson, J.; Mitchell, P.; Bietila, E. From the field: A participatory approach to assess labor inputs on organic diversified vegetable farms in the Upper Midwestern USA. Renew. Agric. Food Syst. 2017, 34, 1-6. [CrossRef]

41. Hoffman, V.; Probst, K.; Christinck, A. Farmers and researchers: How can collaborative advantages be created in participatory research and technology development? Agric. Hum. Values 2007, 24, 355-368. [CrossRef]

42. Hernández-Morcillo, M.; Burgess, P.; Mirck, J.; Pantera, A.; Plieninger, T. Scanning agroforestry-based solutions for climate change mitigation and adaptation in Europe. Environ. Sci. Policy 2018, 80, 44-52. [CrossRef]

43. Camilli, F.; Pisanelli, A.; Seddaiu, G.; Franca, A.; Bondesan, V.; Rosati, A.; Moreno, G.M.; Pantera, A.; Hermansen, J.E.; Burgess, P.J. How local stakeholders perceive agroforestry systems: An Italian perspective. Agrofor. Syst. 2017, 92, 849-862. [CrossRef]

44. Viaene, J.; Van Lancker, J.; Vandecasteele, B.; Willekens, K.; Bijttebier, J.; Ruysschaert, G.; De Neve, S.; Reubens, B. Opportunities and barriers to on-farm composting and compost application: A case study from northwestern Europe. Waste Manag. 2016, 48, 181-192. [CrossRef]

45. Fantappiè, M.; Lorenzetti, R.; De Meo, I.; Costantini, E.A. How to improve the adoption of soil conservation practices? Suggestions from farmers' perception in western Sicily. J. Rural Stud. 2020, 73, 186-202. [CrossRef]

46. Renna, M.; Montesano, F.F.; Signore, A.; Gonnella, M.; Santamaria, P. BiodiverSO: A Case Study of Integrated Project to Preserve the Biodiversity of Vegetable Crops in Puglia (Southern Italy). Agriculture 2018, 8, 128. [CrossRef]

47. Conversa, G.; Lazzizera, C.; Bonasia, A.; Cifarelli, S.; Losavio, F.; Sonnante, G.; Elia, A. Exploring on-farm agro-biodiversity: A study case of vegetable landraces from Puglia region (Italy). Biodivers. Conserv. 2019, 29, 747-770. [CrossRef]

48. Di Silvestro, S.; Strano, M.C.; Ferlito, F.; Torrisi, B.; Allegra, M.; Neri, D.; Lodolini, E.M.; Bella, S. A new emergency for the Mediterranean fruit trees: Detection and characterization of a fungal disease on fig (Ficus carica L.) in Sicily. Acta Hortic. 2021, in press.

49. Lodolini, E.M.; Ferlito, F.; Neri, D. Pruning fig (Ficus carica L.) during the early stages after planting. Acta Hortic. 2021, in press. 
50. Cicala, A.; Continella, A.; Ferlito, F. Preliminary Results of Primocane-Fruiting Red Raspberry Cultivars in Sicily. Acta Hortic. 2002, 585, 191-195. [CrossRef]

51. Stati Generali Agricoltura: Stato di SALUTE DEL COMParto. AGR Basilicata. Available online: https://www.regione.basilicata.it/ giunta / site /Giunta / detail.jsp?otype=1012\&id=3052391\#: \{\{:text=Donne.,regioni \%20con\%20incidenza\%20pi\%C3\%B9\%20alta (accessed on 7 May 2021).

52. Ceccarelli, D.; Ciaccia, C.; Canali, S. I Dispositivi Sperimentali di Lungo Periodo per l'agricoltura Biologica. In BIOREPORT 2019. L'agricoltura biologica in Italia; Abitabile, C., Marras, F., Viganò, L., Eds.; Rete Rurale Nazionale 2014-2020: Roma, Italy, 2020; pp. 161-179.

53. Eyhorn, F.; Muller, A.; Reganold, J.P.; Frison, E.; Herren, H.R.; Luttikholt, L.; Mueller, A.; Sanders, J.; Scialabba, N.E.-H.; Seufert, V.; et al. Sustainability in global agriculture driven by organic farming. Nat. Sustain. 2019, 2, 253-255. [CrossRef]

54. Wezel, A.; Brives, H.; Casagrande, M.; Clément, C.; Dufour, A.; Vandenbroucke, P. Agroecology territories: Places for sustainable agricultural and food systems and biodiversity conservation. Agroecol. Sustain. Food Syst. 2015, 40, 132-144. [CrossRef] 